\title{
UJI AKTIVITAS ANTIBAKTERI FRAKSI BATANG PEPAYA (Carica Papaya Linn.) TERHADAP BAKTERI Staphylococcus Aureus
}

\author{
Handayani, Kristina ${ }^{1}$ ), Amalia Eka Putri ${ }^{1}$, Rahma Diyan Martha ${ }^{1}$ \\ ${ }^{1}$ Prodi S1 Farmasi, STIKes Karya Putra Bangsa, Tulungagung, Jawa Timur, Indonesia \\ email: kristinahandayani289@gmail.com
}

\begin{abstract}
Infectious disease is an important disease in Indonesia. Infectious diseases can be caused by pathogenic microorganisms such as the bacterium Staphylococcus aureus ATCC 25923. Infectious diseases can be treated with antibiotics, but antibiotics now experience resistance. Therefore, other alternatives such as are needed papaya stem which can be used as an antibacterial against S.aureus ATCC 25923. The purpose of this study was to determine the antibacterial activity against S.aureus ATCC 25923 and to know the MIC value in the most active fraction of papaya stem fraction. Papaya stem sample extracted using a method soxhletation with $96 \%$ ethanol followed by fractionation using three solvents namely aquadestilate, dichloromethane, and nhexane. The positive control used is clindamycin and the negative control is the solvent appropriate. The most active fraction is tested to determine the minimum inhibition concentration (MIC) using a visual and observation Uv-Vis spectrophotometer. Statistical analysis is done with Kruskal Wallis and Mann Whitney. The results of testing the antibacterial activity of papaya stem fractions showed the presence of antibacterial activity against S.aureus ATCC 25923. The inhibitory zone results in aquadestilate, dichloromethane, and $n$-hexane fractions were $20.63 \pm 0.28$ $\mathrm{mm}, 17.86 \pm 0.18 \mathrm{~mm}$, and $15.33 \pm 0.47 \mathrm{~mm}$, respectively. The papaya stem fraction which has the most active inhibition zone is the aquadestillate fraction. The antibacterial activity is thought to originate from a flavonoid, tannin, and saponin compounds activity in papaya stem fraction. The minimum inhibitory concentration value of the aquadestillate fraction is $0.312 \%$.
\end{abstract}

Keywords: Antibacterial, Carica papaya L., Minimum Inhibitory Concentration, Staphylococcus aureus ATCC 25923

\begin{abstract}
ABSTRAK
Penyakit infeksi merupakan salah satu penyakit yang penting di Indonesia. Penyakit infeksi dapat disebabkan dari mikroorganisme patogen seperti, bakteri Staphylococcus aureus ATCC 25923. Penyakit infeksi dapat diobati dengan pemberian antibiotik, akan tetapi antibiotik sekarang mengalami resistensi. Oleh karena itu, diperlukan alternatif lain seperti batang papaya yang dapat di manfaatkan sebagai antibakteri terhadap S.aureus ATCC 25923. Tujuan penelitian ini adalah untuk mengetahui aktivitas antibakteri terhadap S.aureusATCC 25923dan mengetahui nilai KHM dalam fraksi teraktif fraksi batang pepaya. Sampel batang papayadiekstraksi menggunakan metode sokletasi dengan etanol $96 \%$ dilanjutkan fraksinasi menggunakan tiga pelarut yaitu aquadestilata, diklorometana dan $n$-heksan. Kontrolpositif yang digunakan adalah klindamisin dan kontrol negatif adalah pelarutyang sesuai. Fraksi teraktif dilakukan pengujian untuk mengetahui konsentrasi hambat minimum (KHM) menggunakan pengamatan secara visual dan spektrofotometer Uv-Vis. Analisa statistik dilakukan dengan Kruskal Wallis dan Mann Whitney. Hasil pengujian aktivitas antibakteri fraksi batang papaya menunjukkan adanya aktivitas antibakteri terhadap S.aureus ATCC 25923. Hasil zona hambat pada fraksi aquadestilata, diklorometana dan n-heksan berturut-turut
\end{abstract}


adalah $20,63 \pm 0,28 \mathrm{~mm}, 17,86 \pm 0,18 \mathrm{~mm}$ dan $15,33 \pm 0,47 \mathrm{~mm}$. Fraksi batang papaya yang memiliki zona hambat paling aktif adalah pada fraksi aquadestilata. Nilai Konsentasi Hambat Minimum fraksi aquadestilata adalah 0,312\%.

Kata kunci: Antibakteri, Carica papaya L., konsentrasi hambat minimum, Staphylococcus aureus ATCC 25923

\section{PENDAHULUAN}

Penyakit infeksi merupakan salah satu penyakit yang menjadi masalah kesehatan masyarakat yang penting, khususnya di negara berkembang seperti Indonesia (Kemenkes, 2011).Penyakit infeksi dapat disebabkan dari mikroorganisme patogen seperti, bakteri Staphylococcus aureus ATCC 25923(Kemenkes, 2011). Penyakit infeksi dapat diobati dengan pemberian antibiotik namun sekarang obat antibiotik mengalami resistensi karena faktor penggunaanya yang kurang tepat (Adzkie et al., 2017). Pembuatan obat antibiotik selain dari bahan kimia juga dapat dibuat dari tanaman berkasiat obat, salah satu tanaman yang bisa digunakan sebagai obat antibiotik yaitu tanaman pepaya (Primadiamanti et al., 2018).

Batang pepaya merupakan salah satu bagian dari tanaman papaya yang dapat di manfaatkan sebagai antibakteri.Batang pepaya mengandung senyawa metabolit sekunder golongan saponin, tanin, dan flavonoid yang digunakan sebagai antibakteri(Simbolon et al., 2018). Menurut Rahman et al., (2011) ekstrak batang pepaya pada konsentrasi $1 \%$ memiliki aktivitas antibakteri paling efektif terhadap Staphylococcus aureusATCC 25923dengan diameter zona hambat sebesar $12 \mathrm{~mm}$ termasuk dalam kategori kuat.

Penelitian yang dilakukan oleh Rahman et al., (2011)belum dilakukan fraksinasi, sehingga perlu dilakukan fraksinasi untuk mengetahui kandungan senyawa kimia pada ekstrak batang papaya. Fraksinasi mampu mengoptimalkan potensi dan memperluas spektrum aktivitas maserat tumbuhan (Huda et al., 2019).Tujuan penelitian ini adalah untuk mengetahui aktivitas antibakteri fraksi batang pepaya terhadap S.aureus ATCC 25923dan mengetahui nilai KHM dalam fraksi teraktif batang pepaya.

\section{BAHAN DAN METODE}

\section{Alat dan Bahan}

Alat yang digunakan adalah ayakan mesh 80 , neraca analitik, oven, labu alas bulat, statif dan klem, kondensor, waterbatt, gelas beker, tabung reaksi, corong pisah, autoklaf (GEA YX2808), hot plate, cawan petri, kertas cakram, erlenmeyer, aluminium foil, use, mikropipet, inkubator (model DNP Electro Thermal Incubator), spektrofotometer Uv-Vis N4S.

Bahan yang digunakan dalam penelitian ini merupakan batang pepaya segar, etanol $70 \%$, etanol 96\%, n-heksan, diklorometana, aquadestilata, magnesium $(\mathrm{Mg})$, asam klorida $(\mathrm{HCl})$ pekat, larutan feri klorida $\left(\mathrm{FeCl}_{3}\right) 1 \%$, Nutrient agar (NA), Nutrient broth (NB), $\mathrm{NaCl}$ fisiologis, $\mathrm{Mc}$ Farland, klindamisin dan Staphylococcus aureus ATCC 25923 yang berasal dari USBE Laboratorium Iso Universitas Setia Budi.

\section{Metode}

Penelitian ini dilakukan di Laboatorium Mikrobiologi STIKes Karya Putra Bangsa Tulungagung, sejak Januari 2020 sampai Juni 2020. Batang pepaya yang digunakan berasal dari Wonodadi Blitar, Jawa Timur.

1. Determinasi tanaman

Determinasi tanaman bertujuan untuk mengetahui kebenaran identitas tanaman. Sampel tanaman batang pepaya di determinasi di UPT Materia Medica, Batu, Jawa Timur. Tujuan dari determinasi merupakan untuk mengetahui kebenaran jenis tanaman (Insanu et al., 2011). 


\section{Pembuatan simplisia}

Batang yang digunakan dalam penelitian ini adalah batang pepaya yang berumur yaitu 1 tahun 3 bulan yang terdapat di kabupaten Blitar dan telah dilakukan determinasi. Batang dicuci sebanyak tiga kali dan dilakukan pemotongan dengan tebal $2-5 \mathrm{~cm}$. Batang pepaya dikeringkan menggunakan oven pada suhu $50^{\circ} \mathrm{C}$. Batang pepaya yang sudah kering kemudian digiling dan diayak menggunakan ayakan 80 mesh.

3. Penentuan kadar air serbuk batang pepaya

Uji kadar air serbuk batang pepaya dilakukan dengan memasukkan kurang lebih $10 \mathrm{~g}$ serbuk dan timbang seksama dalam wadah yang telah ditara. Dikeringkan pada suhu $105^{\circ} \mathrm{C}$ selama 5 jam dan ditimbang. Kadar air pada simplisia tidak lebih dari 10\% (Depkes, 2008). Kadar air yang melebihi $10 \%$ dapat mengakibatkan mudah ditumbuhi jamur (Ratnani et al., 2015).

4. Proses ekstraksi dan fraksinasi

Sampel diekstraksi menggunakan metode sokletasi. Pelarut yang digunakan adalah etanol $96 \%$ dengan perbandingan 1:20. Proses ekstraksi dihentikan apabila cairan yang menetes berubah menjadi jernih (empat kali sirkulasi). Ekstrak yang dihasilkan kemudian dipekatkan dan dilanjutkan fraksinasi menggunakan pelarut yaitu aquadestilata, diklorometana dan n-heksan. Fraksi yang dihasilkan kemudian dipekatkan pada suhu $50^{\circ} \mathrm{C}$.

5. Skrinning fitokimia

a. Tanin

Mengambil fraksi aquadestilata, fraksi diklorometana dan fraksi n-heksanmasing-masing sebanyak $2 \mathrm{~g}$ kemudian menambahkan etanol sampai semua fraksiterendam. Memindahkan sebanyak $1 \mathrm{~mL}$ larutan ke kedalam tabung reaksi dan ditambahkan 2-3 tetes larutan $\mathrm{FeCl}_{3} 1 \%$. Hasil positif mengandung tanin ditunjukkan dengan terbentuknya warna hitam kebiruan atau hijau. Terbentuknya senyawa hijau kehitaman dikarenakan tanin membentuk senyawa komplek dengan ion $\mathrm{Fe}^{3+}$ (Huda et al., 2019).

b. Flavonoid

Mengambil fraksi aquadestilata, diklorometana dan n-heksan sebanyak $1 \mathrm{~mL}$ kemudian mencampurkan dengan $3 \mathrm{~mL}$ etanol 70\%, kemudian dikocok, memanaskan dan mengkocok kembali kemudian menyaringnya. Filtrate yang diperoleh, kemudian menambahkan $\mathrm{Mg} 0,1 \mathrm{~g}$ dan 2 tetes $\mathrm{HCl}$ pekat. Terbentuknya warna merah, orange, atau hijau pada lapisan etanol menunjukkan adanya flavonoid. Terjadinya reduksi dengan $\mathrm{Mg}$ dan $\mathrm{HCL}$ pekat sehingga membentuk senyawa komplek yang berwarna merah (Huda et al., 2019).

c. Saponin

Mengambil fraksi aquadestilata, diklorometana dan n-heksan sebanyak $1 \mathrm{~mL}$ kemudian mencampur dan mendidihkan dengan $10 \mathrm{~mL}$ aquadestilata dalam waterbatt. Mengocok filtrat dan didiamkan selama 15 menit. Terbentuknya busa yang stabil menunjukkan positif terdapat saponin. Busa yang ditimbulkan karena adanya kombinasi struktur senyawa penyusun saponin yaitu sapogenin non polar dan rantai polar yang larut dalam air (Alamsyah et al., 2014).

6. Uji aktivitas antibakteri fraksi batang pepaya

a. Metode difusi cakram

Kertas cakam steril yang telah diresapi fraksi batang pepaya sebanyak $20 \mu \mathrm{L}$ ditempatkan pada permukaan media yang telah diinokulasi. Kertas cakram ditekan secara lembut kebawah menggunakan pinset steril. Kontrol positif digunakan tablet klindamisin $150 \mathrm{mg}$ 0,001\% dan kontrol negatif yang digunakan adalah pelarut yang sesuai dengan masing-masing fraksi. Setelah itu dilakukan inkubasi selama 24 jam pada suhu $37^{\circ} \mathrm{C}$. Hasil zona hambat yang 
terbentuk diamati secara visual dan diukur diameternya menggunakan mistar berskala kemudian dilakukan analisis statistik.

b. Metode dilusi cair

Metode dilusi dilakukan dengan menyiapkan 12 tabung steril. Kontrol positif yang digunakan adalah suspensi bakteri dan kontrol negatifnya adalah fraksi aquadestilata. Konsentrasi larutan stok yang dibuat adalah 5\%. Pengenceran dibuat secara aseptis dengan deret konsentrasi yaitu kontrol $(-) ; 5 \% ; 2,5 ; 1,25 \% ; 0,625 \% ; 0,312 \% ; 0,156 ; 0,078 \% ; 0,039 \% ; 0,019 \% ; 0,009 \%$ dan kontrol (+). Media NB dimasukkan $0,5 \mathrm{~mL}$ pada tiap tabung. Fraksiaquadestilata sebanyak $1 \mathrm{~mL}$ dimasukkan secara aseptis pada tabung 1, kemudian pada tabung 2 dimasukkan sebanyak $0,5 \mathrm{ml}$. Dari tabung 2 dipipet $0,5 \mathrm{~mL}$ dan dimasukkan ke dalam tabung 3 kemudian dihomogenkan. Pada tabung 3 diambil $0,5 \mathrm{~mL}$ dan dimasukkan dalam tabung 4 begitu seterusnya sampai tabung 11. Dari tabung 11 diambil $0,5 \mathrm{~mL}$ dan dibuang. Suspensi bakteri ditambahkan sebayak $0,5 \mathrm{~mL}$ dari tabung 2 sampai tabung 12. Seluruh tabung diinkubasi pada suhu $37^{\circ} \mathrm{C}$ selama $24 \mathrm{jam}$, lalu diamati kekeruhannya.Konsentrasi hambat minimum dapat diukur kekeruhannya secara visual, dengan cara setelah media tabung perlakuan diinkubasi selama 1x24 jam, semua tabung tersebut dilihat kekeruhannya secara visual. Bila kekeruhan masing-masing tabung masih setara atau lebih keruh dari tabung $\mathrm{K}(+)$ yang berisi suspensi bakteri S.aureus ATCC 25923sesuai standar kekeruhan 0,5 McFarland berarti bakteri masih dapat bertumbuh, tetapi ketika larutan dalam tabung terlihat lebih jernih daripada tabung $\mathrm{K}(+)$ berarti pertumbuhan bakteri mulai terhambat (Lolongan et al., 2016).

\section{Pengujian spektrofotometer Uv-Vis}

Konsentrasi hambat minimum juga dapat diukur dengan menggunakan spektrofotometer Uv-Vis dengan panjang gelombang $343 \mathrm{~nm}$ (Warokka et al., 2016). Pengukuran dilakukan dengan cara media yang telah di inkubasi diukur nilai absorbannya, spektrofotometer sebagai nilai absorbansi akhir. Jika nilai absorbansi akhir (sesudah inkubasi) masing-masing tabung lebih besar dari nilai absorbansi awal (sebelum inkubasi), maka disimpulkan bahwa masih terjadi pertumbuhan bakteri, namun jika tidak terdapat perubahan nilai absorbansi antara nilai absorbansi akhir dengan absorbansi awal, atau nilai absorbansi akhir lebih kecil dari nilai absorbansi awal, maka disimpulkan bahwa pertumbuhan bakteri dihambat. KHM ditentukan dengan konsentrasi fraksi terkecil pada tabung perlakuan yang sudah mulai menghambat pertumbuhan bakteri (Lolongan et al., 2016).

\section{ANALISIS DATA}

Data yang digunakan pada analisis hasil adalah data kuantitatif. Data kuantitatif yang dianalisis berupa diameter zona hambat fraksi batang pepaya dan di uji normalitas dengan ShapiroWilk. Apabila data yang dihasilkan tidak terdistribusi normal maka dilanjutkan pengujian menggunakan Kruskal Wallis dan Mann Whitney.

\section{HASIL DAN PEMBAHASAN}

Determinasi, uji kadar air, ekstraksi dan fraksinasi

Hasil determinasi menunjukkan bahwa sampel yang digunakan benar batang pepaya. Hasil uji kadar air memenuhi persyaratan yaitu 7,79\%. Kadar air yang sesuai dengan syarat dapat mencegah pertumbuhan mikroorganisme sehingga simplisia batang pepaya dapat bertahan lama dalam penyimpanan(Depkes, 2008). Simplisia batang pepaya diekstrak menggunakan metode sokletasi menghasilkan rendemen sebesar 5,39\%. Menurut Cahyadi et al., (2018)kualitas ekstrak berbanding terbalik dengan jumlah rendemen yang dihasilkan, semakin tinggi nilai rendemen semakin rendah mutu yang didapatkan sehingga ekstrak yang didapatkan sudah memenuhi persyaratan. Ada beberapa faktor yang dapat mempengaruhi proses ekstraksi yaitu suhu ekstraksi, waktu ekstraksi, komposisi pelarut dan rasio padatan terlarut(Dodyk et al., 2016). Proses 
selanjutnya adalah fraksinasi dimana ekstrak yang dihasilkan dilakukan fraksinasi menggunakan 3 pelarut yaitu aquadestilata, diklorometana dan n-heksan. Hasil determinasi, uji kadar air, rendemen ekstrak dan fraksi dapat dilihat pada Tabel I.

Tabel I. Hasil determinasi, uji kadar air, ekstraksi dan fraksinasi

\begin{tabular}{cllc}
\hline No. & \multicolumn{1}{c}{ Perlakuan } & \multicolumn{1}{c}{ Sampel } & Hasil \\
\hline 1. & Determinasi & Batang pepaya & Batang pepaya (Carica papaya Linn.) \\
2. & Uji Kadar Air Simplisia & Serbuk batang pepaya & $7,7 \%$ \\
3. & Rendemen Ekstrak & Ekstrak batang pepaya & $5,39 \%$ \\
4. & Rendemen Fraksi & Fraksi aquadestilata & $65,32 \%$ \\
& & Fraksi diklorometana & $2,32 \%$ \\
& & Fraksi n-heksan & $6,06 \%$ \\
\hline
\end{tabular}

\section{Skrinning fitokimia}

Skrinning fitokimia fraksi batang pepaya bertujuan untuk memastikan keberadaan seyawa metabolit sekunder yang terkandung didalam batang pepaya (Huda et al., 2019). Hasil skrinning fitokimia dapat dihihat pada Tabel II.

Tabel II. Hasil skrinning fitokimia fraksi batang pepaya

\begin{tabular}{lccc}
\hline \multicolumn{1}{c}{$\begin{array}{c}\text { Golongan } \\
\text { Senyawa }\end{array}$} & Pereaksi & Perubahan Warna & Hasil \\
\hline Flavonoid & $\mathrm{Mg}+\mathrm{HCl}$ Pekat & Jingga Orange & + \\
Saponin & Fraksi+Aquadest & Busa & + \\
Tanin & Etanol $70 \%+\mathrm{FeCl}_{3} 1 \%$ & Hijau Kehitaman & +
\end{tabular}

Keterangan: $(+)=$ terdapat senyawa,$(-)=$ tidak terdapat senyawa

\section{Uji aktivitas antibakteri fraksi batang pepaya}

Uji aktivitas antibakteri fraksi batang pepaya terhadap bakteri Staphylococcus aureus ATCC 25923penting untuk dilakukan dikarenakan bakteri ini dapat menyebabkan infeksi pada manusia seperti pneumonia, jerawat, pioderma dan impetigo.Ujiaktivitas antibakteri fraksi batang pepaya dilakukan untuk mengetahui adanya aktivitas antibakteri fraksi batang pepaya terhadap bakteri Staphylococcus aureus ATCC 25923 menggunakan dua metode yaitu metode difusi cakram dan metode dilusi cair.

a. Difusi

Uji difusi bertujuan untuk melihat ada daya hambat dalam fraksi batang pepaya, dengan ditandai terbentuknya daerah jernih di sekitar cakram. Berdasarkan hasil pengujian aktivitas antibakteri (Tabel 3.) ekstrak dan fraksi batang papaya memiliki aktivitas antibakteri terhadap Staphylococcus aureus ATCC 25923 ditunjukkan dengan adanya daerah jernih disekitar kertas cakram. Hal tersebut diduga karena aktivitas dari senyawa saponin, tanin, dan flavonoid dalam batang pepaya yang digunakan sebagai antibakteri(Simbolon et al., 2018). Hasil zona hambat semua kontrol negatif memiliki rata-rata sebesar $0 \pm 0,00 \mathrm{~mm}$. Hal ini menunjukkan bahwa aktivitas antibakeri yang dihasilkan berasal dari aktivitas fraksi batang pepaya. Hasil dari klindamisin $0,01 \%$ yang digunakan sebagai kontrol positif, semua memiliki zona hambat yang masuk dalam kategori sangat kuat (Pratiwi, 2009). 
JOPS (Journal Of Pharmacy and Science)

Vol. 4, No. 1, Bulan Desember 2020, Hal. 21-30

p-ISSN: 2622-9919; e-ISSN: 2615-1006

Tabel III. Diameter zona hambat uji difusi

\begin{tabular}{|c|c|c|c|c|}
\hline \multirow[t]{2}{*}{ Sampel } & \multicolumn{3}{|c|}{$\begin{array}{c}\text { Diameter Zona Hambat (mm) } \\
\text { Replikasi }\end{array}$} & \multirow[t]{2}{*}{$\begin{array}{c}\text { Rata-rata } \pm \text { Standart } \\
\text { Deviasi }\end{array}$} \\
\hline & 1 & 2 & 3 & \\
\hline $\begin{array}{l}\text { Fraksi Aquadestilata } \\
5 \%\end{array}$ & 20,3 & 20,6 & 21 & $20,63 \pm 0,28$ \\
\hline $\begin{array}{ll}\text { Kontrol } & \text { Positif } \\
\text { Aquadestilata } & \end{array}$ & 26,6 & 27,3 & 27,3 & $27,06 \pm 0,32$ \\
\hline $\begin{array}{l}\text { Kontrol Negatif Fraksi } \\
\text { Aquadestilata }\end{array}$ & 0 & 0 & 0 & $0 \pm 0,00$ \\
\hline $\begin{array}{l}\text { Fraksi Diklorometana } \\
5 \%\end{array}$ & 18 & 18 & 17,6 & $17,86 \pm 0,18$ \\
\hline $\begin{array}{l}\text { Kontrol Positif Fraksi } \\
\text { Diklorometana }\end{array}$ & 27 & 26,6 & 27,3 & $26,96 \pm 0,28$ \\
\hline $\begin{array}{l}\text { Kontrol Negatif Fraksi } \\
\text { Diklorometana }\end{array}$ & 0 & 0 & 0 & $0 \pm 0,00$ \\
\hline Fraksi n-Heksan 5\% & 15 & 15 & 16 & $15,33 \pm 0,47$ \\
\hline $\begin{array}{l}\text { Kontrol Positif Fraksi } \\
\text { n-Heksan }\end{array}$ & 26,6 & 26 & 27 & $26,53 \pm 0,41$ \\
\hline $\begin{array}{l}\text { Kontrol Negatif Fraksi } \\
\text { n-Heksan }\end{array}$ & 0 & 0 & 0 & $0 \pm 0,00$ \\
\hline
\end{tabular}

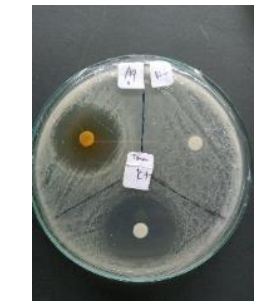

Fraksi Aquadestilata

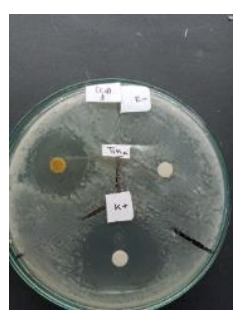

Fraksi Diklorometana

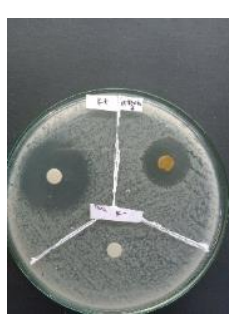

Fraksi n-Heksan

Gambar 1. Uji aktivitas antibakteri fraksi batang pepaya

Hasil zona hambat pada fraksi aquadestilatamemiliki rata-rata 20,63 $\pm 0,28 \mathrm{~mm}$ masuk dalam kategori sangat kuat, fraksi diklorometana memiliki zona hambat rata-rata 17,86 $\pm 0,18 \mathrm{~mm}$ masuk dalam kategori kuat dan fraksi $n$-heksan memiliki zona hambat rata-rata $15,33 \pm 0,47 \mathrm{~mm}$ masuk dalam kategori kuat. Hasil dari masing-masing sampel menunjukkan data yang berbeda-beda sehingga dilakukan uji normalitas data untuk mengetahui apakah data tersebut berdistribusi normal. Nilai uji normalitas data menggunakan Shapiro Wilk didapatkan hasil nilai $\mathrm{p}=0,000(\mathrm{p} \leq 0,05)$ yang berarti data tidak berdistribusi normal. Ketidaknormalan data tersebut dikarenakan perbedaan variansi data yang jauh. Pengujian dilanjutkan pada uji nonparametrik Kruskal Wallis.Hasil uji Kruskal Wallis didapatkan nilai $\mathrm{p}=0,000(\mathrm{p} \leq 0,05)$ yang berarti terdapat perbedaan bermakna pada diameter zona hambat terhadap Staphylococcus aureusATCC 25923dari kelompok perlakuan fraksi batang pepaya. 
Pengujian dilanjutkan uji Mann Whitney untuk mengetahui adanya perbedaan bermakna antara dua kelompok perlakuan. Uji aktivitas antibakteri fraksi batang pepaya yang memiliki zona hambat paling aktif adalah pada fraksi aquadestilata (Gambar 1.) yang ditandai dengan diameter zona hambat paling besar. Fraksi aquadestilata memiliki zona hambat paling besar dibandingkan dengan fraksi diklorometana dan fraksi n-heksan. Berdasarkan uji Mann Whitney nilai signifikansi fraksi aquadestilata sebesar $\mathrm{p}=0,046(<0,05)$ yang berarti fraksi aquadestilata berbeda bermakna dengan kedua fraksi lainnya. Hal ini karena fraksi aquadestilata diduga mampu menarik senyawasenyawa yang bersifat polar seperti flavonoid, saponin dan tanin (Gazali et al., 2019).

b. Dilusi

Hasil uji difusi fraksi teraktif yaitu fraksi aquadestilata dilanjutkan uji dilusi cair dengan variasi konsentrasi $5 \%-0,009 \%$. Uji dilusi cair merupakan suatu metode yang bertujuan untuk mengukur konsentrasi hambat minimum (KHM) dari fraksi aquadestilatabatang pepaya. Uji dilusi ini dilakukan dengan menggunakan metode visual dan spektrofotometer Uv-Vis.

Tabel IV. Pengamatan kekeruhan fraksi aquadestilatasecara visual

\begin{tabular}{ccccc}
\hline $\begin{array}{c}\text { Nomor } \\
\text { Tabung }\end{array}$ & $\begin{array}{c}\text { Konsentrasi Fraksi } \\
\text { Batang pepaya }\end{array}$ & Replikasi I & Replikasi II & Replikasi III \\
\cline { 3 - 5 } & $\mathrm{K}(-)$ & - & - & - \\
2 & $5 \%$ & - & - & - \\
3 & $2,5 \%$ & - & - & - \\
4 & $1,25 \%$ & - & - & - \\
5 & $0,625 \%$ & + & + & + \\
6 & $0,312 \%$ & + & + & + \\
7 & $0,156 \%$ & + & + & + \\
8 & $0,078 \%$ & + & + & + \\
9 & $0,039 \%$ & + & + & + \\
10 & $0,019 \%$ & + & + & + \\
11 & $0,009 \%$ & + & + & + \\
12 & $\mathrm{~K}(+)$ & + & + & + \\
\hline
\end{tabular}

Hasil pengamatan (Tabel IV) nilai KHM secara visual dari fraksi aquadestilata yaitu pada konsentrasi $1,25 \%$. Pada pengamatan ini memiliki kekurangan karena mata manusia tidak dapat membedakan sel bakteri mati dan sel bakteri yang hidup sehingga dapat bersifat subjektif. Pengujian dilanjutkan menggunakan spektrofotometrer Uv-Vis pada panjang gelombang $343 \mathrm{~nm}$ (Lolongan et al., 2016). 
Tabel V. Pengujian nilai absorbansi fraksi aquadestilata menggunakan spektrofotometer Uv-Vis

\begin{tabular}{|c|c|c|c|c|c|c|c|c|c|}
\hline \multirow[t]{3}{*}{$\begin{array}{c}\text { Fraksi } \\
(\%)\end{array}$} & \multicolumn{8}{|c|}{$\begin{array}{l}\text { Hasil Absorbansi } \\
\text { (nm) }\end{array}$} & \multirow[t]{3}{*}{ Ket. } \\
\hline & \multicolumn{2}{|c|}{ Replikasi I } & \multicolumn{2}{|c|}{ Replikasi II } & \multicolumn{2}{|c|}{ Replikasi III } & \multicolumn{2}{|c|}{ Rata-rata } & \\
\hline & (a) & (b) & (a) & (b) & (a) & (b) & (a) & (b) & \\
\hline $5 \%$ & 0,505 & 0,216 & 0,612 & 0,051 & 0,560 & 0,065 & 0,553 & 0,332 & Turun \\
\hline $2,5 \%$ & 0,101 & 4,000 & 0,278 & 0,233 & 0,405 & 0,325 & 0,261 & 1,159 & Naik \\
\hline $1,25 \%$ & 0,456 & 0,253 & 0,489 & 0,103 & 0,370 & 0,385 & 0,438 & 0,247 & Turun \\
\hline $\begin{array}{c}0,625 \\
\%\end{array}$ & 0,325 & 0,238 & 0,270 & 0,208 & 0,118 & 0,090 & 0,237 & 0,178 & Turun \\
\hline $\begin{array}{c}0,312 \\
\%\end{array}$ & 0,231 & 0,148 & 0,350 & 0,385 & 0,284 & 0,172 & 0,288 & 0,235 & Turun \\
\hline $\begin{array}{c}0,156 \\
\%\end{array}$ & 0,347 & 0,533 & 0,388 & 0,507 & 0,296 & 0,512 & 0,343 & 0,517 & Naik \\
\hline $\begin{array}{c}0,078 \\
\%\end{array}$ & 0,291 & 0,389 & 0,472 & 0,434 & 0,496 & 0,501 & 0,419 & 0,441 & Naik \\
\hline $\begin{array}{c}0,039 \\
\%\end{array}$ & 0,191 & 0,215 & 0,267 & 0,275 & 0,322 & 0,455 & 0,260 & 0,315 & Naik \\
\hline $\begin{array}{c}0,019 \\
\%\end{array}$ & 0,214 & 0,475 & 0,210 & 0,366 & 0,259 & 0,382 & 0,227 & 0,407 & Naik \\
\hline $\begin{array}{c}0,009 \\
\%\end{array}$ & 0,550 & 0,769 & 0,132 & 0,294 & 0,870 & 0,567 & 0,517 & 0,543 & Naik \\
\hline $\mathrm{K}(+)$ & 1,021 & 4,000 & 1,256 & 1,343 & 1,289 & 1,463 & 1,188 & 2,268 & Naik \\
\hline $\mathrm{K}(-)$ & 1,430 & 1,395 & 1,433 & 1,405 & 1,416 & 1,387 & 1,426 & 1,395 & Turun \\
\hline
\end{tabular}

Pada konsentrasi 5\% (Tabel V) dan diikuti konsentrasi $1,25 \%$ sampai $0,312 \%$ terjadi penurunan nilai absorbansi. Pada konsentrasi $0,156 \%$ sampai akhir terjadi kenaikan nilai absorbansi sehingga hasil nilai KHM dapat ditetapkan pada konsentrasi $0,312 \%$ ditandai dengan penurunan nilai absorbansi yang paling akhir. Pada konsentrasi 2,5\% terjadi kenaikan nilai absorbansi. Konsentrasi 2,5\% merupakan konsentrasi yang lebih tinggi dari pada konsentrasi $1,25 \%$ yang seharusnya dapat menghambat bakteri. Kenaikan nilai absorbansi tidak sepenuhnya terjadi karena pertumbuhan bakteri, tetapi dapat dipengaruhi oleh kepekatan konsentrasi yang lebih tinggi, sehingga dapat memengaruhi penyerapan cahaya oleh sel bakteri yang mati.

\section{KESIMPULAN}

Fraksi aquadestilata, diklorometana dan n- heksan batang papaya memiliki aktivitas antibakteri terhadap bakteri Staphylococcus aureus ATCC 25923 yang ditandai dengan adanya zona hambat pada media tanam. Fraksi aquadestilata batang pepaya merupakan fraksi paling aktif sebagai antibakteri terhadap Staphylococcus aureus ATCC 25923 dengan diameter zona hambat sebesar $20 \mathrm{~mm}$ dan nilai KHMnyasebesar 0,312\%. 
JOPS (Journal Of Pharmacy and Science)

Vol. 4, No. 1, Bulan Desember 2020, Hal. 21-30

p-ISSN: 2622-9919; e-ISSN: 2615-1006

\section{UCAPAN TERIMA KASIH}

Peneliti mengucapkan terimakasih kepada semua pihak yang telah banyak membantu baik moril maupun materi dalam menyelesaikan penelitian ini

\section{REFERENSI}

Adzkie Muhammad, Nunuk Aries Nurulita, A. B. F. (2017) 'Uji Sensitivitas Antibiotik Terhadap Bakteri Penyebab Infeksi Saluran Kemih Pada Pasien Rawat Inap Di RSUD PROF. DR Margono Soekarjo Purwokerto', Pharmmacy, 14(2), pp. 247-263.

Alamsyah, H. K. and Widowati, I. W. dan A. S. (2014) 'Aktivitas Antibakteri Ekstrak Rumput Laut Sargassum cinereum (J.G. Agardh) DAari Perairan Pulau Panjang Jepara Terhadap Bakteri Escherichia coli Dan Staphylococcus epidermidis', Journal of Marine Research, 3(2), pp. 69-78.

Cahyadi, J., Satriani, G. I. and Gusman, Ery Weliyadi, E. S. (2018) 'Skrining Fitokimia Ekstrak Buah Mangrove (Sonneratia alba) Bioenrichment Pakan Alami Salina', Jurnal Borneo Saintek, 1(3), pp. 33-39.

Depkes (2008) Farmakope Herbal Indonesia Edisi I. Jakarta: Departemen Kesehatan Republik Indonesia.

Dodyk Pranowo, Erliza Noor, L. H. dan A. M. (2016) 'Optimasi Ekstraksi Flavonoid Total Daun Gedi ( Abelmoschus manihot L .) dan Uji Aktivitas Antioksidan', Bul. Littro, 27(1), pp. 3746.

Gazali, M., Nufus, H. and Nurjanah, Z. (2019) 'Ekaplorasi Senyawa Bioaktif Ekstrak Daun Nipah ( Nypa fruticans Wurmb ) Asal Pesisir Aceh Barat Sebagai Antioksidan', JPHPI, 22(1), pp. $155-163$.

Huda, C., Putri, A. E. and Sari, D. W. (2019) 'Uji aktivitas Fraksi Dari Maserat Zibethinus folium Terhadap Escherichia coli’, Jurnal SainHealth, 3(1), pp. 7-14.

Insanu, M. and Ruslan, Komar Fidrianny, Irda Wijaya, S. (2011) 'Isolasi Flavonoid dari Daun Durian ( Durio Zibethinus Murr ., Bombacaceae )', Acta Pharmaceutica Indonesia, 36(1), pp. 6-10.

Kemenkes (2011) Pedoman Umum Penggunaan Antibiotik. Jakarta: Menteri Kesehatan Republik Indonesia.

Lolongan, R. A., Waworuntu, O. and Christy N. Mintjelungan (2016) 'Uji Konsentrasi Hambat Minimum ( KHM ) Ekstrak Daun Pacar Air ( Impatiens balsamina L .) Terhadap Pertumbuhan Streptococcus mutans', Jurnal e-GiGi(eG), 4(2).

Pratiwi, Sylvia T. 2009. Mikrobiologi Farmasi. Jakarta: Penerbit Erlangga.

Primadiamanti, A., Winahyu, D. A. and Jaulin, A. (2018) 'Uji Efektivitas Sediaan Salep Batang Pepaya ( C arica Papaya L .) Sebagai Penyembuh Luka', Jurnal Farmasi Malahayati, 1(2), pp. 69-79.

Rahman, S., Imran, M. and Muhammad, N Hassan, N Chisthi, A K Khan, A F Sadozai, K S Khan, S. M. (2011) 'Antibacetial screening of leaves and stem of Carica papaya', Journal of 
JOPS (Journal Of Pharmacy and Science)

Vol. 4, No. 1, Bulan Desember 2020, Hal. 21-30

p-ISSN: 2622-9919; e-ISSN: 2615-1006

Medicinal Plants Research Vol., 5(20), pp. 5167-5171.

Ratnani, R. D. and Hartati, Indah Anas, Yance Endah, Devi P. Khilyati, D. D. D. (2015) 'Standarisasi Spesifik Dan Non Spesifik Ekstraksi Hidrotropi Andrographolid Dari Sambiloto (Andrographis paniculata)', Prosiding Seminar Nasional Peluang Herbal Sebagai Alternatif Medicine, pp. 147-155.

Simbolon Marita TM, Zalfiatri, Yelmira Hamzah, F. (2018) 'Pembuatan sabun transparan dengan penambahan ekstrak batang pepaya sebagai antibakteri', Chempublish Journal, 3(2), pp. 5768. doi: $10.22437 /$ chp.v3i2.5713.

Warokka, K. E., Wuisan, J. and Juliatri (2016) 'Uji Konsentrasi Hambat Minimum ( KHM ) Ekstrak Daun Binahong ( Anredera cordifolia Steenis ) Sebagai Antibakteri Terhadap Pertumbuhan Streptococcus mutans', Jurnal e-GiGi(eG), 4(2), pp. 155-159. 